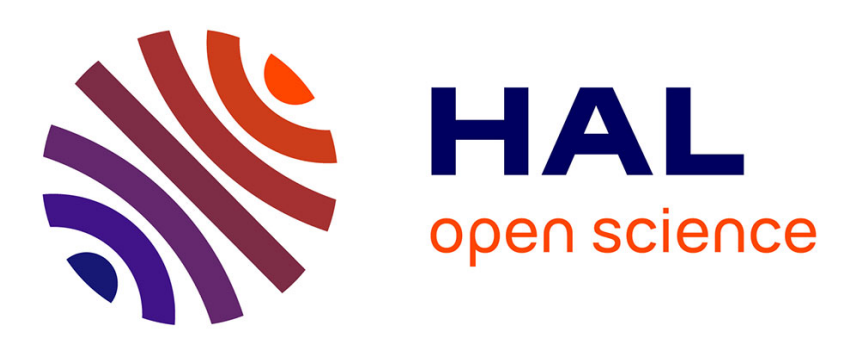

\title{
More than three's a crowd . . . in the best interest of companies!
}

Karima Bouaiss, Isabelle Maque, Jérôme Méric

\section{To cite this version:}

Karima Bouaiss, Isabelle Maque, Jérôme Méric. More than three's a crowd . . . in the best interest of companies!: Crowdfunding as Zeitgeist or ideology?. Society and Business Review, 2015, 10 (1), pp.23 - 39. 10.1108/SBR-09-2014-0042 . halshs-01890575

\section{HAL Id: halshs-01890575 \\ https://shs.hal.science/halshs-01890575}

Submitted on 8 Oct 2018

HAL is a multi-disciplinary open access archive for the deposit and dissemination of scientific research documents, whether they are published or not. The documents may come from teaching and research institutions in France or abroad, or from public or private research centers.
L'archive ouverte pluridisciplinaire HAL, est destinée au dépôt et à la diffusion de documents scientifiques de niveau recherche, publiés ou non, émanant des établissements d'enseignement et de recherche français ou étrangers, des laboratoires publics ou privés. 


\title{
More than three's a crowd...in the best interest of companies! \\ Crowdfunding as Zeitgeist or ideology?
}

\author{
Karima Bouaiss, Isabelle Maque, Jérôme Meric \\ Research Centre for Management, University of Poitiers, Poitiers, France
}

\section{Introduction}

As any neologism, "crowdfunding" could be considered a faddish concept linked with temporary social trends (such as crowdsourcing or micro-funding in the sole area of financial practices) and contemporary economic contexts (financial crisis, credit crunch, etc.). Nevertheless, an historical view on alternative ways of raising funds shows this practice is far from being substantially new, the only novelty proceeding from technologies (i.e. internet) and vocabulary (Castrataro, 2011). Thus the term "crowdfunding" would be worth being examined, so as to determine if it only reflects a contemporary make up for old ideas, or, on the contrary, if it is meaningful of a deep change in social structures. But wherever the true meaning lies between these two extremes, the use of "crowd" as a "key actor" should be examined more thoroughly, as well as the process of funding, which covers different fields of practices. Indeed, considering society through the only scope of crowd may seem quite reductive, unless it proves some ideological usefulness.

The term crowdfunding is supposed to have been used for the first time in August 2006 by a US digital experimenter, Michael Sullivan, when launching his "fundavlog" project, an attempt of incubator for videoblog related events (Maguire, 2013). A few months before in the same year (in June), the word crowdsourcing was coined by Jeff Howe in Wired (14.06). The trick consisted in replacing "out" with "crowd" in the term "outsourcing". Once again, crowd as a concept appears to be central to the development of internet based economic practices. So, far beyond the "bubble" it may depict, the term "crowdfunding" could be significant of a Zeitgeist (in the meaning of Schumpeter, 1954), as Howe himself seems to confirm it when asked to confirm paternity (in Biewald, 2009). If an additional proof of the preeminence of the reference to "crowd" was to be found, it could be done by a 
short analysis of how terminology around such concepts is consolidating presently. As far as English denominations are concerned over the last 6 years, crowdsourcing has been preferred to competing expressions such as participative funding, peer-funding, fan-funding and micro-funding. We may assume that this preference is not accidental, but that it is significant of a deeper social trend.

A Zeitgeist is defined by Schumpeter as a civilization or as a spirit of the times. As a concept, it is fairly well adapted to what we are trying to analyze, namely the social discourse underlying some internet based economic and emerging social practices. As opposed to social structures that guide behaviors in straight directions, the Zeitgeist synthesizes the ambiguities and the contradictions of a historical period. As Schumpeter contends, it is "an imperfect synthesis of warring elements and can never be described truthfully in terms of a few consistent 'principles."' (1954, p.371). Consequently, it can be approached through various significant social phenomena. Actually, crowdfunding may be particularly illustrative of a period when the internet just gives access to 'crowds' as no other medium could ever do it before. Indeed, analysts agree on the idea that crowdfunding emerged in this specific technological context, concomitantly with credit shortage for innovation support. Beyond this technical aspect, crowdfunding proposes a support to entrepreneurship, one of the scarce ways out from a stalling social elevator (Piketty, 2014). Facing the present liberal moment (Pesqueux, 2014), collective solutions to diminished social mobility, such as cooperative systems, seem to be out of the question. In this context, it is not surprising to see charity become the pattern of new emerging practices, where a sum of proletarised individuals support somebody who strives to get out from the same social group.

In this paper, we try to decipher the contradictions and the ambiguities of crowdfunding as a term and as a practice in order to reveal the deeper significance of its underlying Zeitgeist. To do so, we follow three steps. In the first one, we underline the ambiguities of crowd as a concept in its traditional meaning as well as in the realities it may depict when referring to connected people. Thereafter, we confront the many practices of crowdfunding with the apparent univocity of this term. These analyses lead us to show how an incantatory use of crowd can conceal an effective profit making process.

\section{Of clouds and crowds: ambiguities and paradoxes of virtual social facts}


The word "crowd" depicts either a large number of people gathered together in a disorganized way, or the mass of ordinary people. When Michael Sullivan called for "funding from the crowd", he clearly alluded to the second meaning of it. Nevertheless, referring to "the mass of ordinary people" in such a context not only implies the acceptance of a rather "disorganized" way of raising or providing funds, but also, it supposes that the internet is a place for a crowd to constitute. Here are two stumbling blocks for a crowd to be an effective and reliable fundraising medium. Nevertheless, the word "crowd" seems to be a key factor of success (or at least a marketing argument) for these new fundraising techniques. This paradox can be understood if some time is taken to stress the ambiguities of such a concept. Ambiguities derive from the syncretism of crowd, and from the decoupling that can be operated when such a concept is implemented on the internet.

\subsection{For better and for worse, syncretism of the crowd}

Crowd is a research object in many fields, from statistical analysis to political science. In this contribution, we mainly adopt the psychological point of view, as far as this approach deals with both the contradictions of crowd and the relation of individuals with this more or less organized mass. It is also helpful to cast light on how the ambiguities of this concept are used in the discourse and the practice of crowdfunding. From this perspective, we can stress at least three intrinsic paradoxes of crowds.

\subsubsection{Wisdom vs. impulsiveness}

The "wisdom of the crowd" is probably one of the first ideas that come to minds when referring to crowdfunding. This legitimating mechanism lies on a shared cultural background in democracies (sovereignty of the people) and on a western representation of the average as truth (it is better to take into account the collective answer to a question than to refer to experts' opinions on the same problem). References to the wisdom of crowds flourish in specialized media and blogs, but it is also instilled in social representations on crowdfunding. When the SEC (Securities Exchange Commission) decided to let small businesses raise money on the internet without having to comply to usual 
fundraising rules (october 2013), one commissioner declared that it was high time "to unleash the wisdom of crowds" by reforming the JOBS Act ${ }^{1}$.

Nevertheless, it should not be forgotten that the first psychological theories of crowd were developed in a context of fear at the end of the nineteenth century. Emerging megalopolises inspired pessimistic anticipations of what such masses could bring about. Le Bon (1895) represented the power of crowd as an exclusively destructive one. Focusing on the individual within the crowd, Freud shows how the mass displaces the super-ego of each member to be replaced with a set of "freed" unconscious minds. This results in the straight expression of simplistic emotions, instead of composed individual ones. In such a context, crowds are much easier to manipulate than single individuals. If not expressed directly, this hypothesis is often suggested as in a famous blog on crowdfunding: "Remember that people buy based on emotion and a crowd funding pitch is exactly that - it's a sale. Believe it or not straightforward sincerity is one of the most appealing emotions out there, making the quiet but emotionally engaging video a huge success with crowd funding site ${ }^{2} . "$ In the same perspective, the New Zealander crowdfunding platform Pledge Me launched a "flash funding mob" in March 2013. It consisted in funding an overdebted family by raising $\$ 1,400$ in less than 10 minutes.

\subsubsection{Freedom vs. domination}

In a rousseauist perspective, giving the power to the mass of ordinary people guarantees freedom for each of them. Once again, this aspect of crowd is overvalued in the main discourse on crowdfunding: the absence of intermediaries lets subscribers free to choose the projects they want to support, transparency being a key argument to preserve this freedom. The "power of crowd" is not only seen as an economic leverage, but as a renewal of democracy, as testified in an analysis provided by crowdfunded entrepreneurs: "Deep and intertwined in our humanity, is a need to support and feel involvement in the kinds of projects and companies which we care about. Until the recent crowdfunding phenomena emerged, our more centralized and intermediated capital formation and funding mechanisms scarcely recognized the social power of crowds which form affinities around any

\footnotetext{
${ }^{1}$ Source : gigaom.com, SEC votes to "unleash wisdom of crowds," approves crowdfunding rule, J.J. Roberts, Oct. 23, 2013.

${ }^{2}$ Source : http://www.crowdfundingblogs.com/make-your-pitch-pop-with-a-crowdfunding-video/
} 
kind of mission. Crowdfunding is a natural systemic response to fill this gap, and an expression of our collective human will' (Lawton and Marom, 2010, p.1-2).

However, we should remember that masses are also able to develop voluntary servitude (La Boétie, 1975), as Canetti could decipher it through a retrospective on the first 60 years of the twentieth century. Consultancies do insist on the importance of sourcing thought leaders as factor of success in crowdfunding projects, see for instance, the following excerpt of a promotional webpage (Seeding Factory, dec. 2013): “Our staff will help you, 3 weeks BEFORE your campaign starts, to build your own social network and leverage key influencers (bloggers, journalists, thought leaders etc.) to reach a wide audience in your field." Discourse addressed to the crowd is power oriented, when the one addressed to entrepreneurs is based on easier influence of masses.

\subsubsection{Generosity vs. indifference}

Together with wisdom and power, generosity is commonly attached to the concept of crowd. This is particularly true of the crowdfunding discourse, when valuing funders is at stake. Mass generosity is part of the current Zeitgeist, as it penetrates not only opinion, but also politics (funding Barack Obama's first campaign in 2008) and science. Some universities like Murdoch U., Australia, develop research programs on understanding mass generosity. Be it connected with religious feelings (Malloch, 2009) or studied independently from any value system (Mauss, 1925), giving is associated to positive feelings and judgments in the contemporary society. Thus there is no surprise to establish the commitment to give as a major motivator for crowdfunders (Gerber, Hui and Kuo, 2012)

According to darwinian perspectives, altruism results from competition between groups (Darwin, 1872), and has nothing to do with value systems. Furthermore, crowds also have the reputation of being indifferent to many situations. Le Bon would underline that "the functions of governments necessarily increase in proportion as the indifference and helplessness of the citizens grow" (2009, p.250).The indifference of crowds may be well characteristic of ancient forms of societies. This is the hypothesis defended by some supporters of crowdsourcing (Arbix, 2011). Nevertheless, indifference as a potentiality can be twisted into a useful tool in crowdfunding practice. As previously mentioned, crowd manipulation may arouse simplistic emotions like approval or disapproval, but also indifference. Long lasting fundraising projects end up anaesthetizing funders so that bad news may not 
lead to passionate reactions from some supporters. Being not overwhelmed by subscribers' passion becomes a major issue for platform managers.

\subsection{The illusion of online crowds?}

Is crowdfunding as a concept referring to what we commonly name the crowd? To answer this question positively, it would be necessary to wipe out two major paradoxes aroused by the use of the internet in such practices.

\subsubsection{Physical vs. virtual}

As dazzling as it may be, the success of flashmobs should not obscure the fact that such demonstrations are one of the very few examples of embodied crowds aroused by the internet practices. Most cases show virtual crowds, that is ordinary people connected to a same interest pool. Research is still stammering on this question. When 'clouds' are used as a metaphor for a large number of computers through real time communication networks, IT crowds may just be an image to depict online groups of people contributing on a same project at the same time. If such a hypothesis happened to be confirmed, it would mean that the use of crowd is just symptomatic of decoupling in the sense of Meyer and Rowan (1977). If on the contrary, it has to be rejected, the nature of online crowds must be examined and the extension of what has been studied in physical crowds to virtual ones opens avenues for further research, especially in sociology and psychology. Very recent investigations by Stage (2013) tend to show that Le Bon's framework can be easily transposed from body-to-body crowds to online ones, but this is a first step to be followed and extended, all the more it has been implemented on a highly affective blog only.

\subsubsection{Universal vs. exclusive}

Addressing to the crowd conveys the image of universality. Said differently, crowdfunding rides the wave of the internet as a democratic medium. Everybody can access projects they would not even be aware of under former circumstances (Neuman ed., 2002). Free information is made available in proportions that could not be expected before the introduction of this technology and far beyond the borders of Nation States (Cammaerts, 2009, Noveck, 2009). Thus universality is ensured by unlimited 
connectivity, as contended in the "Internet Universality" project supported by the UNESCO. In such a context, the evolution of Law should allow everyone to become a "venture capitalist" (Gobble, 2012). A slight contrast could be found between those generous assertions and the reality of crowdfunding practices. Of course, everybody can take part to this kind of funding projects, as far as in the vast majority of cases, the amount of participation is not fixed in advance, or very low. Nevertheless, management tools developed around crowdfunding turn the practice into an exclusion process. Recent research on crowdfunding shows the interest of market targeting ("tapping the right crowd", Belleflamme, Lambert et Schwienbacher, 2013). The study of motivational variables among potential funders (Gerber, Hui and Kuo, 2012) clearly points out the language elements to be used in order to recruit specific sponsors. Potential crowdfunders becoming an ordinary market, the technology is turned into a powerful tool to reach scattered targets in a geographically flat world (Agrawal, Catalini, and Goldfarb, 2011), far from any democratic ideal.

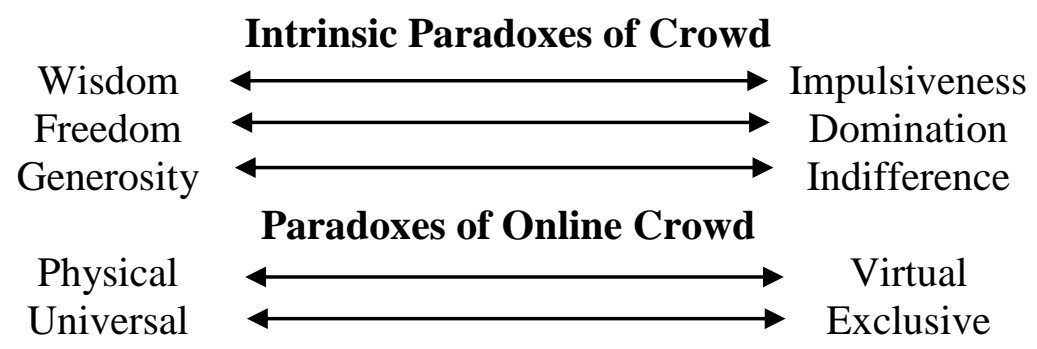

Figure 1: Paradoxes of crowd stemming from the discourse on crowdfunding

Exploring the paradoxes of crowd as a concept and as a technological object makes the case for a schizophrenic nature of discourses and practices of crowdfunding in the present times (see Figure 1). It is now time to extend the exploration to funding as it can be understood in such a context.

\section{Crowdfunding: generosity or expectation of a return on investment?}

Crowdfunding as a practice appears today as a financing method that develops quickly and virally via the Internet. This success is probably due to its simplicity: with a platform on the Internet to meet a financing offer, usually for an artistic project, with online users who are a modern representation of the 
"crowd". These "new investors" (Mairesse, 2013) are offered a number of benefits in exchange for tens or hundreds of dollars. The proposed compensatory measures are often symbolic: thanks on Facebook, invitations on filming, etc... Despite the appearance of a transactional relationship that involves such types of financing, the provider of funds is found engaged in low-paying contract. This relationship is often close to the logic of donation while the receiver raises large sums from the online market. Then the relationship is in favor of the receiver that keeps all decision-making powers without the constraints associated with traditional methods of financing by capital or loans.

\subsection{Crowdfunding: a charity model?}

Crowdfunding is a funding method that takes four main forms: donation without compensation (or gift), rewards, loans or capital investment. We first focus on the first form of financing that is based on donation logic. The donation could be defined as the selling of a good without getting anything returned in particular (Mairesse, 2013).

The logic of donation is based on some more or less disinterested satisfaction of having contributed to the launch and media coverage of art or artists. Yet, donation does not imply a lack of financial or symbolic compensation whatsoever. From a psychological point of view, when a donor is part of a project, it offers him personal satisfaction, especially when he receives thanks and recognition from the project managers he supported. Contributing makes the donors feeling honored, and so this system of donation without getting any compensation in return could be put into questions.

These donors on the Internet act as generous benefactors. Without the help of the funding from the crowd, a lot of projects would have never been financed. This generous funding from the crowd is concomitant with the current evolution of Western countries. Indeed, in addition to crowdfunding on the Internet, young artists can also be funded by an anonymous crowd in various television programs inviting people to vote, by overtaxed sms, for their favorite candidates. These overtaxed sms cost only a few euros to the viewer but ultimately allow to raise large sums in order to fund the program and career of the winner. Nowadays, funding from the crowd donation takes many forms beyond the scope actually structured of online crowdfunding platforms. Another recent example is one of Picasso's paintings. "L'homme au Gibus" has just been "bought" and "won" for 100 euros by an anonymous 
person who participated to a raffle. The crowd allowed the co-financing of the purchase of a painting of exception. These examples may seem surprising and related to the evolution of our time such as the practice of online crowdfunding.

Funding from the crowd finds its meaning in its most philanthropic form in the cultural heritage protection. For instance, the financing of the Statue of Liberty's pedestal was essentially made by donation (100,000 French subscribers donated 400,000 French Francs). Another example is the building of the Mosque Hassan II, a major architectural work, that was financed by Moroccan people whether they lived in Morocco or not. Indeed, King Hassan II obliged his subjects to finance this house of worship for 3,8 billion dirhams. These 2 examples highlight the fact that the funding from the crowd can be either voluntary or sometimes forced. Public authorities use crowd philanthropy to cofinance maintenance, restoration or construction of public monuments. Obviously, those responsibilities are mostly thought as inherent to governments.

It is also clear that funding from the crowd through donations is an ancient practice. Historically, funding by the crowd was used to finance houses of worship belonging to the Abrahamic religions. Small amounts were regularly given by the faithful to the religious institutions. Moreover, people sporadically financed projects requiring large budgets as the expansion or development of places of worship. This logic of donation by the crowd can also be noticed in the funding of museums (Mairesse, 2013). In its modern form, crowdfunding enabled the Louvre Museum to raise a million euros from 7,200 donors in order to buy "Les Trois Grâces" by Lucas Cranach in 2010. Similarly, in 2013 more than 4,000 donors raised funds for two ivory statuettes valued for 800,000 euros. In addition to its modern online form, generous and anonymous crowd takes more institutionalized forms across "museum friends' societies" to support a particular museum. In exchange for financial membership, these "friends" are invited to various events organized by the museum. Today, sites like myartinvest.com allow investments on contemporary and modern worldwide artists with listed works. Each work is divided into 100 shares. Once the 100 shares are purchased, owners can speculate on their purchases. Owners with at least five shares can keep the work at home for a month in exchange for a deposit. Investors can sell their shares to buy something else or wait a few years. The site is then responsible for selling the work at the best price. 
The generosity of crowds allows the financing of projects for substantive amounts. However, the donation involves three stages: giving, receiving and reciprocating (Mauss, 1925). The "giving" stage corresponds to the necessary initial step for the creation and maintenance of social relationships; "receiving" consists in accepting the social bond; and "reciprocating" implies a demonstration of our liberality, honor and wealth (Mauss, 1923). Giving is not a spontaneous act but a "social fact" which implies the acceptance of the gift and the obligation against a donation. Since Antiquity, Aristotle pointed out that the receiver has the right not to return back the gifts he received. This logic stands out contractual relations in the market where financial and in-kind exchange is organized. Within the logic of donation, crowdfunding can lead to disappointment and frustration on the part of the donor when no counter-gift is planned for him. The result may be negative comments posted online by the donor on the crowdfunding website. Conversely, the requirements imposed by the donor can be so heavy that the receiver would probably regret having accepted the gift. Thus, crowdfunding websites' responsabilities can be questioned in order to find the right fit in this non-transactional relationship by crowdfunding gift.

\subsection{Crowdfunding: a transactional relation on the online financial market?}

In addition to donation without compensation (gift) or reward, crowdfunding can take on more traditional forms of financing, such as loans or capital investment. Crowdfunding does not take the institutionalized form of banks and shareholders, but organizes an online capital market. In this second form, the crowdfunding website is comparable to a "financial intermediary" which facilitates the matching of supply and demand of funds. Same mechanisms are prevailing in financial markets or in the banking relationships.

Crowdfunding by loan allows collecting funds for a project or a firm and gives the right to online lenders to be paid back the principal plus interest. Crowdfunding websites act as financial intermediaries, but without having the status of chartered banks. Currently, the debate is ongoing on the regulation of these banking activities, which are exercised by crowdfunding websites without the approval of supervisory authorities. Some crowdfunding websites can work with banks on the feasibility study of projects, but online lenders provide most of the loaned funds. Online lenders 
therefore act as informed depositors who choose their borrowers. Unlike a bank, the relationship between the crowdfunding website, similar to a bank, the CEO and the crowd is only transactional. This relationship is based on hard information available online and not on soft information collected from a relationship based on confidence and built over time (Stein, 2002). The transactional relationship between these different actors is also contractual and legally binding.

In France, various crowdfunding websites by loans can be mentioned as Spear, which was created in 2011. Spear's aims are to finance SMEs with the support of banking partners and online lenders. Babyloan or Microword are other examples of websites, which are intended to facilitate the access of micro-credit to micro-entrepreneurs from developing countries under the best possible conditions. Entrepreneurs present their project to online lenders together with the amount of funds they need to carry out. To date, Babyloan intervenes in 13 countries with more than 17,000 members to 10,000 loans to 10,000 small businesses. Microworld operates in 8 countries for nearly 2,200 projects funded. In its final form, crowdfunding by capital investment allows online users to take shares in the capital of companies. In this financing way, online investors essentially finance start-ups and will be paid only if the company makes profit. These start-ups financed by crowdfunding are characterized by their high degree of risk and are often related to the Internet and ITs. In the latter case, crowdfunding is nearly similar to institutionalized funding of risk capital and especially funding that can be invested in start-ups by business angels.

For instance, Anaxago, which was established in 2012, specialized in the investment of start-ups at the seed funding stage, allows a maximum of 150 investors to become shareholders with a minimum ticket of 1,000 euros. The additional advantage of this website is to provide some investment advice and support to management teams. Similarly, the smartangels.fr website organizes online meetings between entrepreneurs and investors. Investors can manage their investment portfolios online and entrepreneurs have the opportunity to interact directly with their shareholders.

The following table shows the various features of the four possible crowdfunding forms. Indeed, with crowdfunding by loans or capital investment, the same characteristics of financial instruments available in banks or in financial markets are noticed. This consideration fully reproduces the traditional market logic that provides entrepreneurship funding, when crowdfunding by donation is 
mainly used to raise funds in arts and culture such as music or cinematographic production. However, it appears that donation as an historical form of funding from the crowd is scarcely found on significant crowdfunding websites. Indeed, crowdfunding platforms are not necessarily mobilized for "pure unconditional gift", which is used primarily for financing houses of worship, humanitarian aid funds or medical research. Selfless altruism based on moral and ethical values of people exist besides crowdfunding processes.

\begin{tabular}{|c|c|c|c|c|}
\hline & \multicolumn{2}{|c|}{ Donation } & \multicolumn{2}{|c|}{ Financial contribution } \\
\hline & Gift & Reward & Loan & Capital \\
\hline Decision power & None & None & $\begin{array}{c}\text { None (at } \\
\text { least directly) }\end{array}$ & $\begin{array}{l}\text { If more than } 50 \% \text { of } \\
\text { the capital structure }\end{array}$ \\
\hline Return & $\begin{array}{l}\text { None or } \\
\text { symbolic }\end{array}$ & $\begin{array}{l}\text { Benefit in kind or } \\
\text { symbolic }\end{array}$ & Interests & Return on Equity \\
\hline $\begin{array}{l}\text { Kind of } \\
\text { relationship }\end{array}$ & \multicolumn{2}{|c|}{$\begin{array}{l}\text { Non-transactional-based on charity } \\
\text { logic }\end{array}$} & \multicolumn{2}{|c|}{ Transactional based on market logic } \\
\hline $\begin{array}{l}\text { Existence of a } \\
\text { contract }\end{array}$ & None & Low & Yes & Yes \\
\hline $\begin{array}{l}\text { Examples } \\
\text { (significant } \\
\text { crowdfunding } \\
\text { platforms) }\end{array}$ & $\begin{array}{l}\text { Fansnextdoor } \\
\text { Oocto }\end{array}$ & $\begin{array}{c}\text { Babeldoor } \\
\text { My Art Invest } \\
\text { Movies angels } \\
\text { People For Cinéma } \\
\text { Projet Cinema } \\
\text { Touscoprod } \\
\text { All In My Music } \\
\text { Buzz My Band } \\
\text { Hubbyz } \\
\text { Music invest } \\
\text { My Major Company } \\
\text { Revenons à la } \\
\text { musique } \\
\text { Serial Liver } \\
\text { Zikaz }\end{array}$ & $\begin{array}{c}\text { Babyloan } \\
\text { Kiss Kiss } \\
\text { Bank Bank } \\
\text { Mailforgood } \\
\text { Microworld } \\
\text { Spear } \\
\text { Xetic }\end{array}$ & $\begin{array}{c}\text { Anaxago } \\
\text { Finance Utile } \\
\text { Fondatio } \\
\text { Friendsclear } \\
\text { Happy capital } \\
\text { Particeep } \\
\text { Reservoir Funds } \\
\text { SmartAngels } \\
\text { Z'Entreprendre } \\
\text { Arizuka } \\
\text { U'Start'Me } \\
\text { WiSEED } \\
\text { ZeGive }\end{array}$ \\
\hline
\end{tabular}

Table 1: Different forms of crowdfunding, examples of French Crowdfunding Platforms

The recurring double ambiguity of crowd as a concept and of funding as a practice can be summed up as in figure 2. The profile of any crowdfunding operation, including its promotional discourse, could be coded by completing such tables (it will be done in the next paragraph, see Figure 3). For instance, such a coding would make visible the decoupling of freedom based discourse and the moral obligation to subscribe to the Hassan II Mosque project. 


\begin{tabular}{|c|c|c|c|c|c|c|c|}
\hline \multicolumn{2}{|c|}{} & Impulsiveness & & $\begin{array}{l}\text { crowdfunding } \\
\text { Charity use of } \\
\text { crowdfunding }\end{array}$ & Physical & Virtual & \\
\hline Wisdom & Domination & & Universal & Exclusive & \\
\hline Freedom & Indifference & & $\begin{array}{c}\text { Transactional } \\
\text { use of } \\
\text { crowdfunding }\end{array}$ & & \\
\hline Generosity & & & & & \\
\hline
\end{tabular}

Figure 2 : Paradoxes of crowd and ambiguities in crowdfunding practices

This double ambiguity (both theoretical and practical) of crowdfunding calls for a deepened analysis of its very nature. Is it to be considered leverage or ideology?

\section{Crowd as leverage or as ideology?}

Varied and various examples of crowdfunding projects, press TV and radio focus and economic and financial data lead people and the crowd to believe that everything is possible thanks to crowdfunding... But is it not only a discourse used to justify facts from companies or public authorities in a specific zeitgeist?

\subsection{Crowd as leverage: some pieces of evidence?}

It is not possible presently not to hear, watch or read about crowdfunding. The profusion of shows, press articles or detailed experiences of projects, very positively focused, highlights the leverage role of crowdfunding. But economic and financial data, even if increases are high from year to year, remain modest compared to other funding modes.

\subsubsection{Extreme variety and originality of crowdfunding projects}

There exists a tremendous and extreme variety and originality of crowdfunding projects, wether it be the objective of the project itself or the chosen funding mode. Let's just give two recent examples. A man, formerly working in communication, wants to open a hotel for cats thanks to crowdfunding (donation), which will be called Aristide, name of his cat, with 20 bedrooms of 4 square meters each in Paris. Stays will include all modern conveniences for felines: food, well fitted bedrooms, games and cosy cushions ${ }^{3}$. Far from this project, Heloïse, a French student, had the idea to use crowdfunding

\footnotetext{
${ }^{3}$ Source: http://www.rtl.be/info/monde/france/1054180/paris-bientot-un-hotel-tout-confort-pour-chats, December 11, 2013
} 
(loan) to get money till she receives her scholarships from French organisations CROUS and CNRS4. Thus, Vincent Ricordeau tells that he, and his two associates, created French crowdfunding platforms Kisskissbankbank and Hellomerci "to free the creativity that dozes in each of us. We think that this ability to fund projects between individuals represents one of the impetus that will change the world" (Ricordeau, 2013).

\subsubsection{The power of words and success stories}

The French national news radio France Info entitles its programmes on crowdfunding as follows: "Crowdfunding, the new citizen power", "A new way of funding for those who want to create their own firm", "Crowdfunding, a new way to reinflate Economy?", "Crowdfunding: a way to finance (all) your projects without a bank" ${ }^{25}$ Media therefore emphasize the leverage role of crowdfunfing in a moribund economic and financial environment. Another illustration of the highlighted leverage role of crowdfunding is the wide circulation of success stories in the media. Thus, a French TV web-series called "Noob" pulverised the European record. Eight days before the end of the call for donation, the producers had collected over half a million of euros, while they had considered 35000 euros. Another success story belongs to the video game sector which has been from the start a huge user of crowdfunding. Thus, in February 2012, Double Fine Productions studio asks for funds on Kickstarter in order to finance the development part of an adventure game called "Double fine Adventure". The sum asked for is 400,000 dollars. In less than 24 hours, one million dollars is collected! One element that explains this enthousiasm is the creator of the game who is also the creator of others famous games; thus, money came from reputed game developers as well as internet users, happy to get cheaply the new game (compensation/reward) ${ }^{6}$. Lawton and Marom (2013) therefore defend in this way that "Ever since the day the first human being approached a prospective investor, the province of capital allocation has been controlled by a small and entrenched minority. All this has changed. Now, the power of the Internet, particularly social media, enables anyone to connect with more investors in less time than it used to take to connect with one".

\footnotetext{
${ }^{4}$ Source: http://etudiant.lefigaro.fr/les-news/actu/detail/article/le-crowdfunding-nouveau-sesame-pourfinancer-ses-etudes-3628/, December 6, 2013

${ }^{5}$ Source : http://www.franceinfo.fr/liste/crowdfunding-0, January 8, 2014

${ }^{6}$ Source : Financement; Les jeux vidéo, superstars du financement par les internautes, La Tribune, September 21,2012
} 


\subsubsection{Growing economic and financial data}

Numerous press articles and crowdfunding professionals insist on the fast development of crowdfunding, mainly, in North America, even if the collected sums remain modest in comparison with funding sources. Thus, crowdfunding platforms collected 2.7 billion dollars in the world in 2012 . The money collected in 2013 could be close to 5.1 billion dollars according to the American consulting firm Massolution. Moreover, another great interest is the role of crowdfunding in the funding of SMEs, particularly since the financial crisis of 2008: in 2012, SMEs received close to 100 million dollars in donation (with or without compensation), 650 million dollars in loans and close to 40 million in equity. But at the same time 35.8 billion euros of consumer credit were granted in France in 2012.7. Thus, France welcomes more or less 25 crowdfunding platforms, 35,000 internet users who funded close to 15000 projects for a total amount of close to 6 million euros from 2008 till today ${ }^{8}$. Investment through crowdfunding in France represented 25 million euros in 2012 and should be close to 80 in $2013^{9}$. Data are impressive, increase rates are high from year to year but very modest compared to other funding modes.

3.2. Crowd as ideology: is crowdfunding the solution to firm's problems?

Ideology as a system of ideas, opinions and believes can influence individual and community behaviors. Is crowdfunding a true answer to present intensified funding and growth problem or only a discourse used to justify facts (and particularly exploitation) from companies or public authorities in a specific zeitgeist?

3.2.1. Crowdfunding as the ultimate solution for funding problem

Several testimonies of SMEs and start-up firms explain the recent use of crowdfunding after not getting the expected help from banks. Thus the founder of SME Yassa Fast Food, specialized in African cuisine explains that the firm has always been short in terms of funding and that "we even had

\footnotetext{
${ }^{7}$ Source : Financement participatif : la collecte va quasiment doubler en 2013, Les Echos, April 16, 2013

${ }^{8}$ Source : Financement participatif; Le "crowdfunding" européen interpelle Michel Barnier, Les Echos, December 20, 2012

${ }^{9}$ Source: BPI website, visited on September 30, 2013
} 
to use crowdfunding, because we failed settling an agreement with our banks"10. Another firm, Monette, specialized in lingerie, was created in summer 2012 with ressources from the former and shut down Lejaby firm and the help from public authorities. The new CEO tells that she got the awaited financial support neither from public authorities (she speaks of "feebleness") nor from bank $\mathrm{BPI}^{11}$ (she tells that BPI "is even more difficult to deal with than other banks") and so turned to crowdfunding past mid-november. She then tells "It is the first time we use this funding mode which really fits our values" and adds "we truly need this equity to continue to develop the company". They expect to collect 800000 euros in two months but on the 8th of January 2014, so close to the deadline, 294850 euros are collected. Above examples tell that crowdfunding was not the first choice of funding of both firms but even came as last recourse. The two other examples detailed above, the hotel for cats' project and the student's need of money before she gets her scholarships, showed huge variety and originality of projects using crowdfunding but why did they really use crowdfunding? Is it because this funding mode boosted creativity or because of the exclusion from a more conventional funding mode? Empirical evidence shows that most members of the crowd in crowdfunding projects are more motivated by non-monetary value and return (Drury and Stott, 2011, Belleflamme et al. 2013) and "typically do not look much at collaterals or business plans" (Lehner, 2013). Crowd focuses less on return and risk, the two inescapable pillars of banks and professional investors, and companies could take advantage of this.

\subsubsection{Financial crisis and pushy public authorities}

Bernard Cohen-Hadad, president of the think tank Etienne Marcel and president of the funding commission of firms belonging to the CGPME, explains that (1) our French SMEs do not have enough equity which slows down their development and makes difficult bank fundings (Internal and prudential ratios limiting the risk taking of Banks), (2) our SMEs should take advantage of both the fast and broad development of information technologies and social networks in every area of our everyday life, and that (3) saving from French people is abundant, represents 3600 billion euros but are merely useful to our Economy. This saving should therefore be oriented towards the funding of

\footnotetext{
${ }^{10}$ Source : Ils réussissent malgré la crise, Les Echos, February 7, 2013

${ }^{11}$ BPI or Banque Publique d'investissemen; The Public Investment Bank was created in 2012 by the new French government in order to straighten up the Economy of France
} 
SMEs, which creates jobs and growth. Thus bank funding represents $90 \%$ of the European GDP whereas in the States it represents no more than $15 \%$.

Following this reasoning, public authorities confirm their will to create conditions in order to develop crowdfunding $^{12}$. The legal hazy and ill-adapted framework is presently being discussed and modified $^{13}$. Even the BPI or Public Investment Bank promotes crowdfunding through the new portal "TousNosProjets.fr" which objective is to "simplify the search for projects and so will increase fundings and the number of contributors" ${ }^{\prime 14}$. Once more, the underlying explanation of the crowd being less sensitive to return and risk and motivated by non-monetary value and return is present.

\subsubsection{Crowdfunding as a free resource for firms}

Larralde and Schwienbacher (2012) distinguish between active and passive crowdfunding. Passive crowdfunding limits the interaction between the company and its crowd to rewards, for example tailored products, whereas in Active crowdfunding, the authors explain that investors are not only supplying money but are also in the best manner of crowdsourcing included in a constant dialogue with the company, helping for example in designing features, testing products, suggesting paths for the company and supplying their network scope and individual expertise. Thus, Jean-Luc Vallejo, a French engineer, developed an application for tablets and used Kickstarter to fund his project. He tells: "in accordance with demands, functionalities were reworked, this relationship with consumers is far more precious than any market study to improve your product" ${ }^{\prime 1}$. Video games consumers' community is very active and asks for high level of participation due to the interactive nature and the development process of games. Thus designers of games tells that successful crowdfunding projects and most active ones allowed the crowd to contribute particularly in a creative way by designing characters, accessories, landscapes or even the story of the game.

Active crowdfunding is also very fruitful in providing a means for corporate communication and public relations and through the dispersed positive discourse improving the legitimacy of the

\footnotetext{
${ }^{12}$ Le financement des start-up, motif d'inquiétude en France, Les Echos, January 21, 2013 ; Financement des start-up : la plateforme de crowdfunding Wiseed a levé un million d'euros, Les Echos, Mai 23, 2013

${ }^{13}$ L'autorité des marchés prête à favoriser le développement de la finance participative, Les Echos, June 25, 2013, Financement alternatif; Crowdfunding : le temps de la réglementation est venu, La Tribune, June 5, 2013 ${ }^{14}$ Source: BPI website, visited on September 30, 2013

${ }^{15}$ Source : Le phénomène du crowdfunding, Des millions de contributeurs pour financer des millions de projets, Le nouvel économiste.fr, visited on January 10, 2014.
} 
company. Thus, Jean-Luc Vallejo tells that beyond funds, crowdfunding process brings credibility, confidence and legitimacy.

The above developed elements tend to show that crowdfunding serves a discourse used to justify companies' doings (or the ones of public authorities) in a specific Zeitgeist. It is thus possible to show the ambiguity between discourse and practice through the intrinsic paradoxes of crowd and the paradoxes of online crowd; the ambiguity refers to charity models but also to transactional models (see figure 3). 


\begin{tabular}{|c|c|c|c|}
\hline \multicolumn{4}{|c|}{ Intrinsic Paradoxes of Crowd } \\
\hline & Discourse & & Practice \\
\hline Wisdom & $\begin{array}{l}\text { *The extreme variety and originality of CF projects invoque the wisdom of } \\
\text { crowd: "to free the creativity that dozes in each of us", "the impetus that } \\
\text { will change the world" } \\
\text { Ex: A hotel for cats or A loan to a French student till she receives her } \\
\text { scholarship } \\
\text { **The power of words and success stories invoque the wisdom of crowd: } \\
\text { Ex: "the new citizen power" or CF as a "new way to reinflate Economy" }\end{array}$ & Impulsiveness & $\begin{array}{l}\text { The mix between the extreme variety and originality of CF projects and } \\
\text { funding motivated by non-monetary value and return invoque } \\
\text { impulsiveness of the crowd in its fundings: } \\
\text { Ex: A hotel for cats made for felines' lovers: "the hotel is called Aristide, } \\
\text { name of the entrepreneur's cat; the hotel will have all modern conveniences } \\
\text { for felines or Loans for people wanting to help people and more precisely } \\
\text { students: The loan to a French student, Héloise, till she receives her } \\
\text { scholarship. }\end{array}$ \\
\hline Freedom & $\begin{array}{l}\text { *The extreme variety and originality of CF projects allows a high level of } \\
\text { freedom in choices of projects: } \\
\text { Ex: From a hotel for cats to a loan to a French student till she receives her } \\
\text { scholarship } \\
\text { **The power of words and success stories allows a high level of freedom } \\
\text { in choices of projects: } \\
\text { Ex: "A way to finance all your projects without a bank" }\end{array}$ & Domination & $\begin{array}{l}\text { *CF is often considered as the ultimate solution for funding problem and } \\
\text { motivated by non-monetary value and return: } \\
\text { Ex: "we even had to use CF, because we failed settling an agreement with } \\
\text { our banks." Or "we truly need this equity to continue to develop the } \\
\text { company." } \\
\text { ** Pushy public authorities want to solve the shortage of public and private } \\
\text { fundings (Banks) through the modification of the CF legal framework in } \\
\text { order to use the huge amount of savings from French people } \\
\text { ***Firms get from the crowd valuable resources for free: } \\
\text { Ex: Active CF is not only supplying money but is also a constant dialogue } \\
\text { with the company, that is to say helping for example in designing features, } \\
\text { testing products, supplying their network scope or individual expertise; } \\
\text { Video games consumers community is thus very active. }\end{array}$ \\
\hline Generosity & $\begin{array}{l}\text { *The generosity of the crowd can express itself through the extreme variety } \\
\text { and originality of CF projects: } \\
\text { Ex: From a hotel for cats to a loan to a French student till she receives her } \\
\text { scholarship } \\
\text { ** Success stories tell the generosity of the crowd: } \\
\text { Ex: "8 days before the end of the call for donation, the producers had } \\
\text { collected over half a million of euros, while they had considered } 35000 \\
\text { euros." }\end{array}$ & Indifference & $\begin{array}{l}\text { *Firms choosing CF as the ultimate solution for funding problem can face } \\
\text { the indifference of crowd: } \\
\text { Ex: "They expect to collect } 800000 \text { euros }(\ldots) \text { [but] close to the deadline, } \\
294850 \text { euros are collected. } \\
* * \text { Economic and financial data related to CF remain modest compared to } \\
\text { other funding modes: } \\
\text { Ex: "in } 2012 \text {, SMEs received close to } 100 \text { million dollars in donation, } 650 \\
\text { million dollars in loans and close to } 40 \text { million in equity } \\
* * * \text { There exists } 3600 \text { billion Euros of savings from French people whereas } \\
\text { French SMEs do not have enough equity. }\end{array}$ \\
\hline \multicolumn{4}{|c|}{ Paradoxes of Online Crowd } \\
\hline & $\begin{array}{ll}\text { Discourse } \\
\end{array}$ & & Practice \\
\hline Physical & $\begin{array}{l}\text { In active CF, we talk about very active "consumers community": } \\
\text { Ex: Video games consumers community is very active and asks for high } \\
\text { level of participation due to the interactive nature and the development } \\
\text { process of games }\end{array}$ & Virtual & $\begin{array}{l}\text { Passive CF limits interaction and CF projects often refers only to } \\
\text { connecting people to a same pool of interest. } \\
\text { Ex: The modification of the CF legal framework in order to use the huge } \\
\text { amount of savings from "French people", French people are seen as a } \\
\text { whole, a virtual whole. }\end{array}$ \\
\hline Universal & $\begin{array}{l}\text { CF projects see every person as a potential investor, that is to say the whole } \\
\text { crowd: }\end{array}$ & Exclusive & $\begin{array}{l}\text { Participation in CF projects remains exclusive : } \\
\text { Video games consumers community is very active but remains also }\end{array}$ \\
\hline
\end{tabular}


Ex: The modification of the CF legal framework in order to use the huge

amount of savings from "French people" refers to French people as a

specific

whole; French people are all seen as potential investors

\section{Figure 3: Ideological aspects of crowdfunding (see Figure 2 for the colour coding)}




\section{Conclusion: crowd, crowdfunding - two ideologies with strong leverage}

Crowdfunding as an emerging practice could have been named in many different ways such as microfunding, microfinancing, peer-funding, etc. The choice of crowd as the key reference to depict this new social phenomenon is nothing but innocent. As far as this specific topic is concerned, crowd is much more leverage as a term than it is as reality. Though it adopts many diverging features, casual crowdfunding induces counterparts and often reproduces market logics. After all, the entrepreneurship oriented crowdfunding operates according to the patterns of Property Rights Theory (Alchian \& Demsetz, 1973). The novelty of crowdfunding lies in the transactional implementation of charity logics: people who are blocked in the social elevator pay for people who want to get out of it, but would like to be paid or "rewarded" in return. The reference to the "crowd" is essential to make such a social evolution acceptable. Actually, crowdfunding compensates for institutional financial disintermediation where charity was previously conceived to compensate for the disintermediation of social action.

This ideological aspect should not obscure the fact that a practice is developing to provide funds where institutional financing does not operate (or stopped operating many years ago). There lies the real leverage of crowdfunding, and probably avenues for future research on this topic. Presently, financial markets and banks in several European countries seem to resist towards crowdfunding, claiming for restrictive rules. But in the same time, several banks are developping their own crowdfunding platforms. This paradox is nothing but innocent.

\section{References}

Agrawal A., Catalini C. and Goldfarb A. (2011), "The Geography of Crowdfunding”, Working Paper, NET Institute Working Paper Series.

Alchian A. A., Demsetz H. (1972) "The paradigm of Property Rights", The Journal of Economic History, 33 (1), pp. 16-27. 
Arbix D. (2011), "The Indifference of the Crowds? User Generated Content, Crowdsourcing, and Risk-Shifting”, working paper, Universidade de Sao Paulo, Brasil.

Belleflamme P., Lambert T., Schwienbacher A. (2013), "Crowdfunding: Tapping the Right Crowd", Journal of Business Venturing, forthcoming.

Biewald L. (2009), "Crowdsourcing the origin of the word "Crowdsourcing", in Crowdflower Blog, 06.02. (https://crowdflower.com/blog/2009/02/crowdsourcing-the-origin-of-the-word-crowdsourcing/)

Cammaerts B. (2009), Internet- Mediated Participation Beyond the Nation State, Manchester University Press, Manchester.

Canetti E. (1960), Crowds and Power. English translation in 1984, Farrar, Strauss \& Giroux, New York.

Castrataro D. (2011), “A Social History of Crowdfunding”, Social Media Week, December $12^{\text {th }}$ (http://socialmediaweek.org/blog/2011/12/a-social-history-of-crowdfunding/\#.UsRci-J v08).

Darwin C. (1872), The Expression of the Emotions in Man and Animals, John Murray, London.

Drury J. and Stott C.(2011), "Contextualising the Crowd in Contemporary Social Science", Contemporary Social Science, 6 (3), pp. 275-288.

Freud S. (1981), Group Psychology and the Analysis of the Ego, Standard Edition, vol. XVIII, pp. 67143. The Hogarth Press, London.

Gerber E.M., Hui J.S., Kuo P.Y. (2012), "Crowdfunding: Why People Are Motivated to Post and Fund Projects on Crowdfunding Platforms", Working paper, Northwestern University, Creative Action Lab.

Gobble M. A. M. (2012), "Everyone Is a Venture Capitalist: The New Age of Crowdfunding", Research-Technology Management, vol.55 n4, $10 \mathrm{p}$.

Howe J. (2006), "The Rise of Crowdsourcing", Wired, 14.06, 4 pages (http://www.wired.com/wired/archive/14.06/crowds.html).

La Boétie E. (1975), The Politics of Obedience: The Discourse of Voluntary Servitude, Ludwig von Mises Institute, Black Rose Books, Montreal.

Larralde B. and Schwienbacher A. (2012), Crowdfunding of small Entrepreneurial Ventures, The Oxford Hanbook of Entrepreneurial Finance, Vol. 369, Oxford University Press.

Lasswell H. (1971), Propaganda Technique in World War I,The M.I.T. Press, Cambridge, MA.

Lawton K. and Marom D. (2013), The crowdfunding revolution, How to raise venture capital using social media, Mc Graw Hill, New York.

Lawton K., Marom D. (2010), The Crowdfunding Revolution: Social Networking Meets Venture Financing, CreateSpace Independent Publishing Platform, Amazon.

Le Bon G. (2009), Psychology of Crowds, Sparkling Books, Southampton. First edition 1895 (French). 
Lehner O. M. (2013), Crowdfunding social ventures: a model and research agenda, Presented first at the 2012 Research Colloquium on Social Entrepreneurship, 16th - 19th July, University of Oxford, Skoll Center of SAID Business School UK.

Maguire A. (2013), Crowdfund It!, Editia, Braddon.

Mairesse F. (2013), "Les modèles participatifs dans les musées", Working paper of Université Paris 3Sorbonne Nouvelle.

Malloch T.R. (2009), Being Generous, Templeton Books, New York.

Mauss M. (1925), Essai sur le don: formes et raisons de l'échange dans les sociétés archaïques, l'Année Sociologique, Paris.

Meyer J. W., and Rowan B. (1977), "Institutionalized Organizations: Formal Structure as Myth and Ceremony”, American Journal of Sociology, n83, pp. 340-63.

Neuman L. (ed.) (2002), Access to Information, a Key to Democracy, the Carter Center Editions, Atlanta.

Noveck B. S. (2009), Wiki Government: How Technology Can Make Government Better, Democracy Stronger, and Citizens More Powerful, Brookings Institution Press, Washington, D.C.

Pesqueux Y. (2014), Expectations of society from corporate performance in today's business scenario, working paper, HAL Archives Ouvertes.

Piketty T. (2014), Capital in the 21st century, Cambridge: Harvard University Press.

Ricordeau V. (2013), Le financement participatif bouscule l'économie!, (Pour libérer la créativité), FYP edition, France.

Schumpeter J.A. (1954), History of Economic Analysis, Allen \& Unwin, London.

Stage C. (2013), "The online crowd: a contradiction in terms? On the potentials of Gustave Le Bon's crowd psychology in an analysis of affective blogging", Scandinavian Journal of Social Theory, vol.14 n², pp.211-226.

Stein J. C. (2002), "Information Production and Capital Allocation: Decentralized versus Hierarchical Firms", Journal of Finance, 57, 1891-1921. 